\title{
Poverty and Unemployment Paradox in Nigeria.
}

\author{
Egunjobi, Titilayo Adenike \\ Department of Economics and Business Studies, College of Management Sciences Redeemer's University. \\ Redemption City, Mowe, Ogun State- Nigeria
}

\begin{abstract}
Despite Nigeria's rich endowment with natural resources, its poverty profile presents a sombre picture of a rich nation in decline. Also, the rate of unemployment is high and has been seen to take an increasing turn in form of youth unemployment. Indeed, Nigeria presents a paradox. The country is rich but the people are poor. This study therefore intends to determine the nature of the relationship between poverty and unemployment over the period 1977 - 2010 in Nigeria, and to ascertain the causal link (if any) between poverty and unemployment. In achieving this, the co -integration, error correction modeling and causality test were employed. The study discovered that each and all of the explanatory variables significantly affect poverty and that a long run relationship exists among the variables of the model that, unemployment has a positive influence on poverty while government investment on infrastructures and human investment has a negative influence on poverty. Furthermore, there is no causal link between poverty and unemployment. The study recommended that government should intensify the provision of infrastructures and making and implementation of appropriate polices which will create a conducive environment needed for investment to thrive.
\end{abstract}

Keywords: Poverty, Regression and Unemployment.

\section{Introduction}

Today, poverty is widely addressed as a global problem. Poverty affects over four billion people in the world. It is a critical phenomenon that calls for an urgent attention and solution all over the world. The need to alleviate poverty arises in order to enhance the quality of life through the creation of favorable standard of living by effective production and distribution of consumer goods and services and generation of employment.

Poverty in Nigeria, a country with over 140 million people is all encompassing. The scourge has also shown a rising tendency in the past couple of decades accounting for the nations low development indicators and its ranking alongside the poorest nations in the world [1]

Poverty level in Nigeria is widespread, counter to the wealth of the country that include human, oil, natural gas, solid minerals. Indicators place it among the twenty poorest countries in the world. According to World Bank [2] about 66 per cent of the Nigerian population now fall below the poverty line of about a dollar a day compared to 43 percent in 1985 , this in a country which is estimated to have earned about 280billion US dollars from oil during the past thirty years. It is obvious that the wealth from oil sector has not been felt through many sectors of the economy because poverty is still a growing problem in Nigeria, however if poverty is characterized by hunger, ill health, inadequate or poor housing illiteracy, malnutrition and unemployment then, there is no doubt that the majority of Nigerians are living below the poverty line as set out by the World Bank in 1990.Assessing the world poorest, in 1988, seven out of ten poorest counties were African countries though in 1990 it was six, but by 1995 it had decreased to eight out of ten poorest countries.

The Nigerian situation becomes more pathetic when compared with other less endowed developing countries in Africa and other parts of the third world. In 1990, Nigeria's per capita income of \$240 was well below the average of over $\$ 500$ for sub-Saharan Africa, using per capital income as a measure of poverty, in 1988 the African country with the highest GNP per capital of \$ 2,290 was South Africa, when the world average GNP was $\$ 3,470$.

The severity of poverty in Nigeria is equally glaring when other indicators of services and development are considered. The Vision 2010 Committee Report reveals that:

1. $50 \%$ of Nigerians live below the poverty line.

2. Only about $40 \%$ have access to safe drinking water;

3. About $85 \%$ of the urban population lives in single houses with more than 7 occupants on the average.

4. Only about $62 \%$ of Nigerians have access to primary health care.

5. Most Nigerians take less than one-third of the minimum required protein and vitamins (Report 2010 Committee:Edoh, 2003).

The most pathetic feature of the Nigerian society today is that a majority of its members are living in a state of destitution while the remaining relatively insignificant minority, are living in affluence. These skewed 
economic relations do not reflect the geographic spread of resource endowment; rather it is a product of classical greed, injustice and selfishness, which is beyond any economic principle.

Unemployment is one of the developmental problems that face every developing economy in the $21^{\text {st }}$ century. International statistics portray that industrial and service workers living in developing regions account for about two-thirds of the unemployed.

Globally, world economy has been expanding with healthy growth in both employment and labour productivity. But unemployment remains a problem in many countries. The global unemployment rate in 2005 was 6.3 percent and the rate for sub-Saharan Africa was about 9.5 percent. In the world, almost half of the unemployed people are young, although they make up only 25 percent of the working population (Dorothea, 2006). Global unemployment rose at 55percent between 2007 and 2010 occurred in what ILO terms the Developed Economies and European Union (EU) region, which only accounts for 15 per cent of the world's labour force. The International Labour Organization (ILO) [4] projects a global unemployment rate of 6.1 per cent, equivalent to 203.3 million unemployed, though in 2011, the labour market registered a highly differentiated recovery with persistently high levels of unemployment and growing discouragement in developed countries. Worldwide, 78 million young people were unemployed in 2010, well above the pre-crisis level of 73.5 million in 2007, but down from 80 million in 2009. Unemployment in the 15-24 age groups stood at 12.6 per cent in $2010,2.6$ times the adult rate of unemployment. Suffice to say youth employment is a world priority. The weak recovery in decent work reinforces a persistent inability of the world economy to secure a future for all youth. This undermines families, social cohesion and the credibility of policies.

In a context of declining growth and economic restructuring, the employment situation in Africa has become critical and labour absorption problematic. In particular, the problem of what is generally referred to as youth unemployment has increasingly come to be recognized as one of the serious socio-economic problems currently confronting many developing countries, especially those in Africa. However, statistics showed that Africa, compared to other regions of the world has the largest segment of youth in her population being 36.7 percent in the year 2000 compared to 27.3 percent for the world [5]. In absolute terms, it is estimated that there are presently about 122 million youths on the African continent. An examination of the unemployment profile in Africa shows that unemployment rates are alarming for some African countries, part of which are Botswana $22 \%$ (1995), Algeria 24\% (1995), Tanzania 22\% (1999), South Africa 25\% (1999) and Nigeria 17\% (1995), $19.7 \%$ (2009) (Umo, 2007).

Today, the Nigerian labour market is characterized by high rate of unemployment, low wages and poor working conditions which also brought about other problems such as increase in crime rate, threat to peace and stability, reduction in investment, migration (rural-urban migration), retardation of economic development, the ultimate is lower standard of living brought about by poor income levels, high poverty rates and inequality gaps and rising prices. Although,successive governments at different times recognized this problem,[6] yet the solution so far proffered have been more palliatives. Since, the existing economic and financial structural reforms that have being put in place have not yielded significant results.

Thus, the study aims at examining not only the nature of the relationship between poverty and unemployment but will also determine if there exists a causal link between the two variables. Suffice to say very few works had been conducted on poverty and unemployment alone and doubtfully any testing the causality between the two variables especially on Nigerian data. Most works had been on each or both in relation to economic development, economic growth or in relation to other macro economic variables.

\section{Poverty and Unemployment: The Nigerian Experience}

Although poverty has become an international concept, poverty in Nigeria is traceable to mismanagement of the Nigerian economy by successive Government both military and civilian. Frequent changes in government have led to sharp changes in economic and social policies, which have impacted adversely on the population and have worsened income distribution.

World Bank Report showed that in 1985 about $43 \%$ of the population was living below the poverty line of N395 a year, this number had declined to 34\% by 1992. But poverty increased between 1992 and 1993 because of adverse policy changes. Moderate poverty was reported to have fallen from $31 \%$ in $1985 / 86$ to 20.5 in $1992 / 93$, while extreme poverty rose marginally from $12 \%$ in $1985 / 86$ to $13.6 \%$ in $1992 / 3$. Also, the incidence of poverty has consistently been on the increase, in 1980 it was $27.2 \%$, in 1985 it was 46.3, in 1992 it was $42.8 \%$ and in 1996 , it was $65.6 \%$. it was also observed that $28.1 \%$ of the total population was chronically poor in 1980 while the percentage had increased to $65.6 \%$ in 1996. Again in $199927.2 \%$ of Nigerian population fell above poverty line and in affluent category. $48.5 \%$ was poor, below poverty line. $24.3 \%$ was categorized as been in extreme poverty category. By the year 1992, 22.0\% was regarded as affluent that is above poverty line. $34.0 \%$ was regarded as poor, below poverty line. The remaining $44 \%$ was regarded as being in extreme poverty category. [7] Furthermore, the UNDP Human Development Index (HDI) for 2001 ranked Nigeria as $142^{\text {nd }}$ 
position with HDI of 0.40 among the poorest countries. The CIA fact book revealed that $70 \%$ of the Nigerian population lives below poverty line in 2007.

In recent times, the incidence of unemployment in Nigeria has been deep and widespread, cutting across all facets of age groups, educational strata and geographical entities. One peculiar features of unemployment problem in Nigeria is that it was more endemic in the early 1980s than any other period. Unemployment has been categorized as one of the serious impediments of social progress. Apart from representing a colossal waste of country's manpower resources, its generate welfare loss in terms of lower income and well-being. On the current trend and nature of unemployment problem, national unemployment recorded some marginal decline between 1981 and 1986, the rate were relatively higher than what obtained in the 1960s and 1970s. The unemployment rate rose from 3.1 percent in 1977 to 6.4 percent in 1980, it later oscillated between 6.4 and 6.1 percent during 1980 to 1985 periods. This development was as result of the stillness in the economy during the period. National unemployment rate figures fluctuated in downward direction from 1986 to 1990 , declining from 5.3 percent to 3.5 percent but the structural Adjustment Programme(SAP), adopted in 1986, had serious implications for the short run unemployment problem. Contrary to the expectation of SAP, which was geared towards encouraging greater employment opportunities in the private sector (especially among the small medium enterprises), the unemployment rate rose from 5.3percent to 7.0 percent in 1987 . . This was further compounded by the continuation of staff retrenchment and replacement of embargo on employment in the public sector. Besides, the new policy orientation brought about some structural changes within the Nigeria labour market. Sectors such as the oil, banking and external sectors became a "blue chips" as against the public and industrial sectors which used to be the "prime" of the labour market prior to the adoption of SAP in 1986. However, from 1991 to 1995 there was serious reduction in unemployment rate to 3.4 percent and this then increased to double digits of as high as 17.5 per cent in 1999 , though by year 2000 it was 13.1 per cent. This provides evidence that there was no optimal utilization of human resources in spite of the excess amount of labour and this is as a result of macroeconomic mismanagement and lack of direction of past rulers. Since then unemployment rate has continued to fluctuate from 13.6 in 2001 to 13.4 in 2004, 14.9 in 2008 and 21.2 in 2010. (See Graph one)

However, the situation has been compounded by the increasing unemployment of professional such as accountants, Engineers, among others, the increasing trend of graduate turnout each year and the declining labour absorption capacity of the country. According to a survey [8]conducted, graduate unemployment accounted for less than one percent of the unemployment in 1974, by 1984, the proportion rose to four percent for urban areas and 2.2 percent on the rural areas. The acquisition of a University degree was once considered as a sure guarantee for securing a paid employment either in the public or the private sector[8]. The reverse has been the case in Nigeria.

Graph one: Trends in Unemployment Rates in Nigeria.

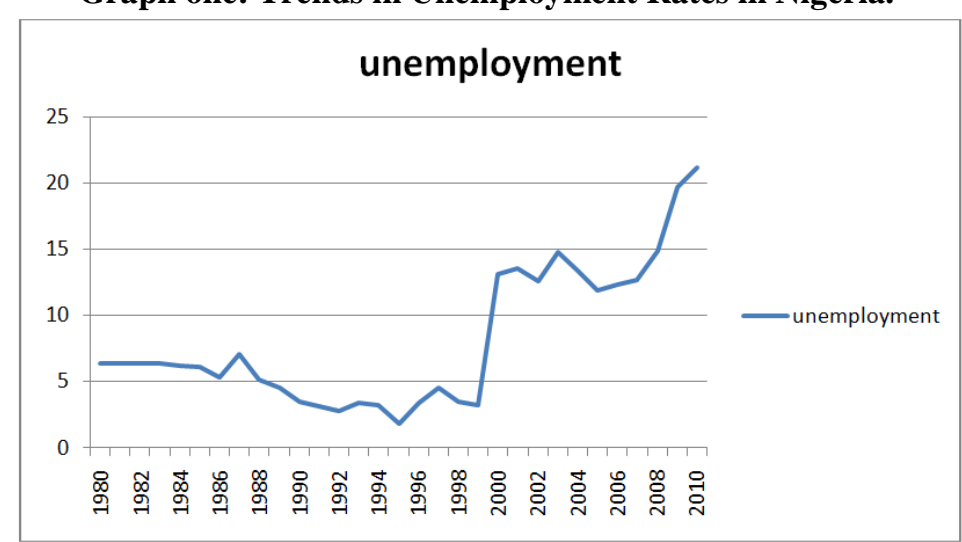

3.1 Poverty

III. Theorectical Framework and Literature Review

Poverty defies objective definition because of its multi-dimensional nature. There is yet no universally accepted definition of poverty. Poverty could be viewed as low income which is insufficient to procure basic goods and services or described [10,2] as those with low income, low education and health, vulnerability in terms of health, income, education, natural disaster, crime and violence, voicelessness and powerlessness (e.g. lacking income earning abilities and mistreatment by state institutions). The poor are those who are unable to obtain an adequate income, find a stable job, lack adequate level of education and cannot satisfy their basic needs. Thus, per capital income is an important measurement of the level of poverty.[11] 
In most cases while defining poverty a distinction is made between absolute and relative poverty. Absolute poverty refers to the lack of minimum physical requirements of a person or household for existence, and is so extreme that those affected are no longer in a position to lead a life worthy of human dignity.[12]. Also, Odusola (1997) in [12] described absolute poverty as lack of adequate resources to obtain and consume a certain bundle of goods and services. Two constraints are identified; one is setting an objective minimum below which an individual or household is considered to be poor while the second is how to set a minimum standard for indicators of basic necessities like food, housing and so on which most often than not vary based on taste, culture and prevailing economic conditions while Relative poverty on the other hand refers to a person or household whose provision of goods is lower when compared with other persons or households within the same income bracket or social standing. It therefore does not imply that the persons concerned cannot lead a life that is worthy of human dignity. Thus relative poverty exists when the subject in consideration is poor in relation to other.

[13] various theories had been advanced in order to put in proper perspectives the mechanisms of poverty. The Orthodox Western views of poverty reflected in the 'Vicious Circle' hypothesis states that a poor person is poor because he wants to be poor and may remain poor unless the person's income level increases significantly enough to pull the person in question out of poverty trap. However the classists believe that such improvements in income or standard of living can only be real and sustained if and only if the population growth is checked and the limits of growth are eliminated. Also, the early classical theorists in the attempt to expatiate on the concept of poverty based their analytical framework on the laws of diminishing return which was believed to be universal, although it was later upgraded by Alfred Marshall and his contemporaries when the law of increasing returns in industry was more clearly articulated.

Perhaps the Marxists introduced a radical change to the perception of poverty by formulating the principle of exploitation of labor. To the Marxists the economy is ultimately controlled and ruled by a few rich capitalists and the masses which form the bulk of the population are made up of poor miserable workers. This was father compounded with the advent of technological progress which was labor saving and resulted in displacement of workers, thereby increasing the reserved army of the unemployed. The unemployed depressed the wage level and effect is increases in poverty which negatively impacts on the development of the country.

Furthermore, Boeke developed the dualistic theories; Social Dualism, Technological Dualism and Financial Dualism. This was later popularized by Aurther Lewis [14]. These theories were characterized by the existence of two parallel institutional production sectors; the traditional sector and the modern sector. In the traditional sector the principle of vicious circle of poverty seems to be institutionalized and was characterized by static low equilibrium conditions, a subsistence life style and cultural value which seems to work in opposition to economic growth and development. The modern sector is dominated by technological investment, innovation, foreign trade and investment and hard work which promotes economic growth and development. Thus it can be inferred that the poor person is the cause of his poverty by remaining rural rather than modern.

The modern approach to poverty considers income as the core of the most poverty related problems. As such poverty may arise from changes in average income or changes in distributed income. Either way there is a general consensus that per capital income is positively related to the measures of well -being. Note should be taken that emphasis is not on the level of per capita income but on how it is distributed.

Poverty can be categorized into five dimensions[15] of deprivation; Personal and physical deprivation, Economic deprivation, Social deprivation, Cultural deprivation and Political deprivation. Personal and physical deprivation is experienced in health, nutrition, literacy, educational disability and lack of confidence. Economic deprivation includes lack of access to property, income assets, factors of production and finance. Social deprivation involves the barriers to full participation in social political and economic life. Cultural deprivation occurs when people are deprived in terms of values, beliefs, attitudes, knowledge, information and orientation and Political deprivation is caused by ignorance which is a deterrent to the elimination of poverty because it complements conditions of exploitation, domination and deprivation.

\subsection{Unemployment}

The ILO categorizes the unemployed as those who either are out of work, want a job, have actively sought work in the last four weeks and are available to start work in the next two weeks or are out of work, have found a job, and are waiting to start it in the next two weeks.

Unemployment in Nigeria can be broadly divided into two; Open unemployment and Disguised unemployment. [16]. Open unemployment is when people who are able bodied and desire to work cannot find jobs to do. While Disguised unemployment involves people who are working full time but whose productivity is so low that a reduction in hours would have an insignificant impact on total output.[17]

Theorectically, the major types of unemployment include: Cyclical unemployment which is the type of unemployment associated with the downturn of the business cycle. The basic cause of cyclical unemployment is a fall in aggregate demand or reduced level of total spending in the economy. Consequently many workers are 
laid off while new entrants into the labour market find it extremely difficult to get jobs. [18]. Such unemployment was noticeable in Nigeria after the era of the first oil boom (1974-1976). A fall in oil earnings, with a consequent squeeze in the budget, meant that many government contracts had to be terminated and new ones were not awarded. This created a recessionary condition causing cyclical unemployment.

Structural unemployment is loss of jobs brought about by changes in the structure of the economy. Such a structural change may be traced to a decrease in demand for a particular item which can also be traced to technological change.

Frictional unemployment is due to lack of information, changes in the supply of labour when wage rates are flexible, etc. This type includes the unemployment of persons who temporarily lose jobs or decide to change jobs, as well as new entrants into labour market like those finishing formal school. The period of unemployment occurs because of the time it takes to find jobs. In Nigeria, this type of unemployment can also be attributed to the existence of "spatial friction". This refers to the fact that distance can pose a problem to labour mobility. Over several decades, most members of the Nation Youth Service Corps (NYSC) have been reluctant to work in rural areas because of the underdevelopment existing in such places. Although the conceptual distinction between frictional and structural employment is tenuous, the main distinguishing characteristic is that, while frictional unemployment involves people with marketable skills such as educational qualifications and experience, structural unemployment involves people whose existing skill are no longer marketable [18]

In another vein, the classical economists believe that with the existence of perfect competition and economic efficiency in the face of many producers and consumers none of which is large enough to influence prices and wages [17] the economy will always tend towards full employment. Such that, the level of employment and subsequently the wage rate are determined simultaneously by the forces of supply and demand. They believed that unemployment will occur when rigidities are present in the wage structure and interferences occur to hinder the free workings of the market system. This could be as a result of trade union activities or minimum wage legislation.

However, this model is limited in the sense that it offers little insight into the practical realities of wage and employment determination of the developing countries. Events indicate that in most developing countries like Nigeria wage rates are typically not flexible downward because they are largely determined by institutional forces including trade union pressures, legislated government salary scales and multinational corporations hiring practices. Accordingly [14], opined that there are many more labourers seeking unemployment at the going wage than there are jobs available such that involuntary unemployment is prevalent.

The New Classical economists believe that as agents continues to optimize, markets will continue to clear, and this implies that involuntary unemployment does not exist. What exists is voluntary unemployment which occurs when rational people voluntarily decide not to work and withdraw their services from the labour market for some reasons.

The New Keynesian school of thought are of the opinion that unemployment arise involuntarily, and they try to adduce reasons why wage does not respond quickly to shifts in the supply and demand in the labour markets and wage rates do not change every time demand or supply shifts. They believe equilibrium in the labour market may not be achievable for extended periods of time and thus unemployment sets in during this period referred to as economic recessions and excess demand during periods of boom. The traditional Keynesians assume that unemployment is as a result of market failure arising out of the imperfections of the free market economy. Attempts were made to explain involuntary unemployment and examine the forces that determine wage-setting and living decisions in what are thought to be more realistic labour market institutions.

Economists are unable to agree on the causes or cure for unemployment. The essence of the Keynesian explanation was that firms demand too little labour because individuals demand too few goods. The Classical view was that unemployment was voluntary and could be cleared by natural market forces. Neo-Classical theory believes that there is a natural rate of unemployment, which reflects a given rate of technology, individual's preferences and endowments. With flexible wages in a competitive labour market, wages adjust to clear the market and any unemployment that remains is voluntary. The latter view was that held by Milton Friedman and strongly influenced government policy in the early 1980'sbut without success. There is, of course, no simple explanation of unemployment and no simple solution.

\subsection{Poverty and Unemployment}

The major macroeconomic objectives of nations include achieving full employment, socially acceptable distribution of income, price stability, economic growth and favourable balance of payment. Most developed nations had been able to achieve these primarily by reducing poverty and curbing the rate of unemployment. However, poverty and unemployment still remains the basic challenges faced by developing nations and some developed nations in recent times. Perhaps the seemingly link between these two variables 
makes it a twin problem since countries recording high unemployment rates especially in the double digit are bedeviled with high rates of poverty.

Perhaps countries in trying to solve these problem tries to tackle each one individually and independently which is why [19] suggested that solution to the problem of unemployment and poverty cannot be found within one single epistemological approach. The reality is that objectives of macroeconomic stability, although necessary in achieving economic growth, is not sufficient for the effective management of the labour market in the context of the lack of access to credit, lack of competiveness, weak infrastructures and other constraints. Evidence in his research is the fact that macroeconomic stability alone cannot reduce poverty. hence it should be accompanied with job creation which will reduce unemployment and other anti- poor strategies should be pursued so as to reduce poverty.

[16] adopted a simple empirical verification to highlight the important role of good macroeconomic management in achieving robust economic growth that can reduce unemployment and poverty. According to him this can be achieved by expanding the level of economic activity and thereby creating employment and generating income. He however also included the role of the private sector, especially the small and medium enterprises and the need to re-examine the educational curriculum of various institutions to ensure that there is an effective nexus between what is produced and what is demanded in the labour market was emphasized, therefore government and the private sector needs to refocus on human investment and training which will reduce unemployment and generate income in the long run.

In his paper, modeling the Nigerian economy for growth and employment [20] proposed a model which he used to reflect some of the key features of the Nigerian economy and the important role of government investment in the economy. His findings show very clearly that increase in domestic investment in the economy either through government or foreign capital has strong positive impact on growth, povety reduction and employment. Based on this findings he suggested that the government should not cut down its investment spending, as was cavassed by some International organisation in the past. Rather it should increase its investment expenditure and possibly retarget it towards the development of infrastructure and human capital. The resultant effect will create a condusive environment necessary for investment which will generate employment and income necessary to reduce poverty and umemployment.

While assessing the macroeconomic analysis of growth, unemployment and poverty in Nigeria using a three stage least square estimation technique on time series data from 1970 - 2000. [21] discovered that poverty is positively related to unemployment rate, this implies that efforts geared towards reducing poverty will have a positive impact on unemployment, thus curbing unemployment.

Accordingly, [22] then provided some basic indicators of the state basic services especially in relation to the poor in Nigeria which can influence poverty such indicators include inequality in income, potable water supply, education and so on. Since poverty could be seen largely in the light of the need for personal growth in Nigeria, which in economic literature is translated to imply basic needs which includes what any society should provide for its members such as food, clothing, shelter, education, health, work and mobility. Under the principle of basic needs, [23] did a comprehensive study on Nigerian poverty. She alluded to the fact that there is substantial under-reporting in basic indicators especially in child mortality, diseases and morbidity. She also states that there is a positive urban bias in government expenditure for basic services significantly inadequate income to meet basic food needs let alone basic services. This presupposes inadequate government efforts in adequately taking care of the poor majority of which are unemployed.

Thus, [24] analyzing the specific roles of public investment in promoting agricultural growth and poverty reduction in India using data from 1970 - 1993, analyzed the components of government expenditure and concluded that government expenditure which not only stimulates growth by generating income but also generating employment is the needed ingredient. Also, empirical evidences in Nigeria, Indonesia and Malaysia also adduce to this fact that generation of employment opportunities will drastically alleviate poverty [21]

Also, [25] is of the opinion that a major means of fighting poverty especially in developing countries is the provision of employment opportunities for the very poor.

[26] making use of a checklist questionnaire analyzed the extent of the mismatch between graduate turnout vis-à-vis their skills and graduate employment as a major cause of poverty in Nigeria, he discovered that graduate turnout outpaced the graduate employment rate over the years in Nigeria.. The study recommended that the issue of mismatch between graduate turnout vis-à-vis their skills and graduate employment should be seriously addressed by taking a three-dimensional approach that involves the tertiary institutions, the government and the labour market since the major cause of poverty in Nigeria is unemployment such that in order to reduce poverty, employment must be generated especially among the graduates.

In his paper on youth unemployment [27] identified the negative consequences of unemployment as poverty, psychological problem, frustration, depression, food insecurity and all manners of criminal behaviour associated with urbanization. Thus in helping to reduce unemployment among the youths poverty will be drastically reduced. 
While providing an analytical framework for poverty reduction in Nigeria, [28] identified unemployment as one of the major causes of poverty in sub -saharan African and suggested investment in human capital via education and training as the way out of poverty if the poor are to enjoy the benefits of democracy. He then concluded that since unemployment was one of the major causes of poverty, all efforts focused on reducing the high unemployment rates in Nigeria via investment in education will directly reduce poverty in Nigeria.

Examining empirically, the role of household physical and human assets endowments as a means of determining poverty in Nigeria between 1985 and 1996 from data collected from national consumer surveys of 1985, 1992 and 1996, [29] estimated the probits for the three periods and found out that household endowments are significant determinant of poverty among both rural and urban households. Out of all these endowments the education of the household stands as the most important determinant of poverty in Nigeria. This implies that education provides access to earning high income which can only be possible when jobs are available, such that the loss of opportunity to earn income will promote poverty.

This is supported by [30], who opined that only those equipped with skills and good health can be employed and earn income. Thus, education, health and general well- being of the majority of people in industrialized nations are as a result of national prosperity which indirectly implies reduction in unemployment and poverty.

\section{Model Specification and Empirical Analysis}

There are indeed many parameters which can be used to measure poverty among which are per capital GDP, per capital income, per capital consumption, poverty rate and so on. However, because some of these indicators cannot be found in a continuous format in Nigeria, this study uses per capital income as indicator of poverty.

Poverty may be a function of unemployment, because it is assumed that unemployment breeds poverty, when people are unemployed, they don't earn income and are bound to be deprived of providing for themselves and their family the basic necessities of life thus higher rates of unemployment may lead to higher levels of poverty. [21,28]

Also government has a social responsibility not only to provide legislation to alleviate poverty, but also to financially back up such legislation, though both the private sector and the public sector has a role to play, government efforts would seem to be more in a developing nation if poverty is to be drastically reduced,not only are they able to reach the majority of people but also provide the necessary infrastructures needed, thus higher government capital investments is expected to lead to lower levels of poverty.[12,20]

Human investment is paramount in reducing poverty especially in a highly populated economy, investment in human resources mainly via education and training will enhance skills and technology required to earn an higher income, increase standard of living and make labour more marketable, thus higher investment in human investment will bring about reduction in poverty. [28]

\subsection{Model Specification}

The model to be estimated in this study is stated as follows:

$\mathrm{PCI}=\beta_{0}+\beta_{1} \mathrm{UNE}+\beta_{2} \mathrm{CAF}+\beta_{3} \mathrm{EDU}+\mu$

$\mathrm{PCI}$ is poverty proxied by per capita income

$\mathrm{UNE}$ is the unemployment rate

CAF is public expenditure on capital proxied by per capita government gross capital formation

EDU is investment in human resources proxied by per capita government capital expenditure on education

$\beta_{0}, \beta_{1}, \beta_{2}, \beta_{3}$ are the parameters of the model.

$\mu$ is stochastic error term.

Apriori it is expected that poverty will be directly related to unemployment rate and indirectly related to government investment and human investment.

\subsection{Sources of Data and Description}

The study used time series data from 1977 - 2010. These data were secondarily sourced from World Bank Publications, Nigeria's Federal Office of Statistics Publications and Central Bank of Nigeria Publications.

\subsection{Estimation Technique}

The test for unit roots and order of integration of the variables was first conducted on the time series data so as to test for stationarity (or non-stationarity). The existence of unit roots in a series denotes nonstationarity. The Augumented Dickey Fuller test was employed in testing for unit root. The ADF test for unit roots specifies if an individual series, say $Y_{t}$, is stationary or not. (Dickey and Fuller, 1979; 1981). Accordingly 
[31] is of the opinion that it is imperative in a data involving macro time series data to test for unit roots and co integration before a structural relationship is estimated and reported for potential policy use.

Also the cointegration analysis introduced by Granger, was conducted in order determine the existence or otherwise of long-run equilibrium relationships among the economic variables. In the event that indeed a long run equilibrium relationship was discovered this implies that even though the series themselves are trended, the difference between them is constant because two or more series move closely together in the long run. However, the absence of cointegration suggests that such variables have no long-run relationship that is in principle they can wander arbitrarily far away from each other [32]

Furthermore, in evaluating the nature of the type of relationship between the variables (positive or negative) and to discover if the variables are significant or not the Ordinary Least Square Regression was employed.

Again, the Error Correction Mechanism was engaged to correct for deviations from the long run equilibrium relationship between the dependent variable and the explanatory variables. It's objective is to specify the short run adjustments dynamics of the equation.

Finally, the causality test was applied in order to determine the direction of causality or otherwise between the variables using the Granger causality test. By definition an economic series $X_{t}$ is said to granger cause $\mathrm{Y}$ if changes in $\mathrm{X}_{\mathrm{t}}$ must precede changes in $\mathrm{Y}_{\mathrm{t}}$ based on the axiom that the past and present may cause the future but the future cannot cause the past (Granger, 1980). Granger tests specifically measures precedence and information content.

\section{TABLE 1: Descriptive Statistics}

$\begin{array}{lcccc} & \text { CAF } & \text { EDU } & \text { PCI } & \text { UNE } \\ \text { Mean } & 11267.95 & 232.2046 & 0.003820 & 7.950000 \\ \text { Median } & 11376.15 & 177.8960 & 0.003264 & 6.200000 \\ \text { Maximum } & 19726.57 & 1082.500 & 0.029713 & 19.70000 \\ \text { Minimum } & 3669.312 & 36.86180 & 0.000301 & 1.900000 \\ \text { Std. Dev. } & 4286.062 & 231.8210 & 0.004705 & 4.915113 \\ \text { Skewness } & 0.093173 & 2.045219 & 5.074368 & 0.727051 \\ \text { Kurtosis } & 2.194331 & 7.218352 & 28.68323 & 2.258311 \\ & & & & \\ \text { Jarque-Bera } & 0.968754 & 48.91209 & 1080.386 & 3.774734 \\ \text { Probability } & 0.616081 & 0.000000 & 0.000000 & 0.151470 \\ & & & & \\ \text { Sum } & 383110.3 & 7894.956 & 0.129895 & 270.3000 \\ \text { Sum Sq. Dev. } & 6.06 \mathrm{E}+08 & 1773452 . & 0.000730 & 797.2250 \\ \begin{array}{l}\text { Observations } \\ \text { Source: Author's }\end{array} & 34 & 34 & & 34 \\ \text { compilation } & & & & \\ \end{array}$

Looking at the statistics of the variables used in the estimation, per capital income averaged N0.0038k and ranges from N0.0003k to N0.0297k, Capital expenditure on infrastructures averaged N11267 and varies from N3669 to N19726 while capital expenditure on education averaged N231 and ranges from N37 to N1083 and unemployment rate averaged $7.95 \%$, recording the lowest rate of $1.9 \%$ while reaching its peak at $19.7 \%$.

4.4 Unit Root and Co integration Test

Time series properties of variables in most economies especially those of developing counties are not very satisfactory and are bound to give spurious result, in order to give a more robust estimation which can then be used for policy recommendations the unit root test is conducted using the Augumented Dickey - Fuller (ADF)

test.

TABLE 2: Result of Stationary (Unit Root) Test.

\begin{tabular}{|c|c|c|c|}
\hline Variables & $\mathrm{ADF}$ - statistics & Critical values & Order of Integration \\
\hline $\mathrm{PCI}$ & -4.471117 & $\begin{array}{l}1 \%=-4.3098 \\
5 \%=-3.5742 \\
10 \%=-3.2217\end{array}$ & $\mathrm{I}(1)$ \\
\hline UNE & -6.287440 & $\begin{array}{l}1 \%=-4.2733 \\
5 \%=-3.5578 \\
10 \%=-3.2124\end{array}$ & $\mathrm{I}(1)$ \\
\hline CAF & -4.273493 & $\begin{array}{l}1 \%=-4.2967 \\
5 \%=-3.5684 \\
10 \%=-3.2183\end{array}$ & I(1) \\
\hline EDU & -7.363039 & $\begin{array}{l}1 \%=-4.2733 \\
5 \%=-3.5578 \\
10 \%=-3.2124\end{array}$ & $\mathrm{I}(1)$ \\
\hline
\end{tabular}


The unit root test result presented in Table 2 shows that all the variables are stationary at their first difference. However estimates of variables at their first difference will only be useful for short run analysis because the parameters contain only short run information. However if the variables are co- integrated then it implies that there exists a long run relationship among them and as such regression results thus conducted will no longer be spurious.( Engel and Granger, 1991). Therefore co -integration test is conducted by taking the residuals from the regression analysis as valid error correction terms and if they are stationary we conclude that the variables are cointegrated.(Adebiyi, 2003)

Table 3: Cointegration Test

\begin{tabular}{|l|l|l|l|}
\hline Variables & ADF - statistics & Critical values & Order of Integration \\
\hline ECM & -5.442061 & $1 \%=-4.2627$ & $\mathrm{I}(0)$ \\
& & $5 \%=-3.5530$ & \\
& & $10 \%=-3.2096$ & \\
\hline
\end{tabular}

Source: Author's computation

Table 3 shows that there is no unit root in the residuals, since it is stationary at levels, it is assumed that all the variables are co integrated at one percent significance level, then it can be inferred that there exist a strong long run relationship between the level of poverty and the other explanatory variables of the model in Nigeria.

\section{5: OLS Regression Result}

TABLE 4: Regression Result

\begin{tabular}{|l|l|l|l|l|}
\hline Variable & Coefficient & t-Statistic & Prob & $\mathrm{R}^{2}=0.517115$ \\
\hline C & 2.110988 & 0.791136 & 0.4351 & AdjR $^{2}=0.468826$ \\
\hline LOGUNE & 0.740237 & 3.374860 & 0.0021 & D.W stat $=1.728824$ \\
\hline LOGCAF & -0.656615 & -2.063767 & 0.0478 & F-stat $=10.70886$ \\
\hline LOGEDU & -0.660618 & -4.554333 & 0.0001 & Prob(F-stat $)=0.000060$ \\
\hline
\end{tabular}

The overall significance of the model is statistically significant at one percent level of significance. This implies a strong linear relationship between the dependent variable and the explanatory variables. As expected, all the independent variables are correctly signed and are significant in explaining the variations in the independent variable. There exists a positive and significant( at5\%) relationship between unemployment rate and poverty, this portrays that a 5\% increase in unemployment rate will lead to over $70 \%$ increase in poverty. As more people become unemployed and are able to earn income by engaging in productive ventures, the general level of poverty will drastically reduce. In accordance with apriori expectation there exist a negative and significant relationship (at $5 \%$ ) between public expenditure on capital and poverty, such that a $1 \%$ increase in public expenditure on capital will lead to about $70 \%$ decrease in poverty. As government continues to provide the necessary infrastructures needed to lay the foundation for investment to strive and boost production then income will be generated and poverty will be curbed. The results also showed that poverty is significantly ( at 1\%) and negatively related to investment in human resources as such a $1 \%$ increase of investment in human resources will lead to above $66 \%$ decrease in poverty.

The coefficient of determination $\mathrm{R}^{2}$ depicts that the explanatory variables accounts for over $50 \%$ of the variations in the level of poverty. The $\mathrm{R}^{2}$ value of 0.52 may seem low. But in regression analysis our objective is not to obtain a high $\mathrm{R}^{2}$ but rather to obtain dependable estimates of the true population regression coefficients and draw statistical inferences about them. The researcher should be more concerned about the logical or theoretical relevance of the explanatory variables to the dependent variable and their statistical significance. If in this process we obtain a high $\mathrm{R}^{2}$, well and good; on the other hand, if $\mathrm{R}^{2}$ is low, it does not mean the model is necessarily bad (Gujarati, 2003). The Durbin- Watson result of 1.73 implies the absence of autocorrelation.

4.5 The Error Correction Model

The Error Correction Mechanism specifies the short run adjustments dynamics and is employed to correct any deviations from the long run equilibrium relationship between the dependent variable and the explanatory variables. The formula for calculating the ECM is presented as $\mathrm{D}(\mathrm{PCI})=\alpha_{0}+\alpha_{1}(\mathrm{UNE})+\alpha_{2}(\mathrm{CAF})+\alpha_{3}(\mathrm{EDU})+\mathrm{ECM}(-1)$

\section{TABLE 5: The Error Correction Model Result}

Dependent Variable is PCI

\begin{tabular}{|l|l|l|l|}
\hline Variable & Coefficient & Standard Error & t-statistic \\
\hline Constant & -169204.0 & 98126.92 & -1.724339 \\
\hline UNE & -59332.77 & 34409.31 & -1.724323 \\
\hline CAF & 52630.61 & 30522.34 & 1.724331 \\
\hline EDU & 52951.92 & 30708.51 & 1.724340 \\
\hline ECM(-1) & -80154.99 & 46484.37 & 1.724343 \\
\hline
\end{tabular}

Source: Author's computation 
The result shows that the coefficients of the explanatory variables are not statistically significant which implies that UNE, CAF and EDU do not affect short run changes in the poverty level. The effect of such changes can only be felt in the long run. The ECM which is the speed of adjustment mechanism is correctly signed and significant at 5\%. This indicates that deviation from equilibrium of the dependent variable (income) will take an adjustment of almost five years before equilibrium can be attained again.

In addition, the Granger causality test was applied in this study as a means of ascertaining causality among the two variables- poverty and unemployment.

Table 6: Causality Test Result

\begin{tabular}{|l|l|l|l|}
\hline Null Hypothesis & Obs & F- Statistic & Probability \\
\hline UNE does not Granger cause PCI & 32 & 0.26340 & 0.7704 \\
\hline PCI does not Granger cause UNE & 32 & 0.09043 & 0.9138 \\
\hline
\end{tabular}

Source: Author's computation

The Pairwise Granger causality test result on poverty and unemployment variables presented in table 8 depicts that there is no causal relationship between the two variables, both are not statistically significant in causing a link between them. None can granger cause the other. Thus we accept the null hypothesis. This implies that poverty does not granger cause unemployment and unemployment also does not granger cause poverty. Neither can significantly determine the other.

\section{Summary, Conclusion and Policy Recommendations}

The study had shown that there exists the problem of poverty and unemployment in Nigeria and using regression analysis on time series data from $1977-2010$ discovered that in Nigeria poverty is positively related to unemployment and negatively related to public expenditure on infrastructures and investment in human resources. Also, there exists a long run relationship but there is no short run relationship between poverty, unemployment, public expenditure on infrastructures and investment in human resources. Furthermore, there is no causal relationship between poverty and unemployment in Nigeria.

The prevailing situation therefore calls for an immediate policy effort to fine-tune the economy in the direction of a reduced poverty and inequality levels to revamp and bolster the economy via generating employment, investing in human development and skill acquisition and providing a favourable environment for investment to thrive.

Thus the following policy recommendations are made;

It has been ascertained that there is a strong link between poverty and unemployment such that creating employment will certainly reduce the level of poverty.

Government should provide the necessary infrastructures needed to lay a solid foundation for investment to thrive, this can be done by not only increasing its capital expenditure but investing it in projects which will generate more externalities than it will consume like energy and transportation. In Nigeria it is also worthy to mention that such allocations/ contracts should be carefully monitored to reduce corrupt practices which bedevils the public sector.

Apart from providing the infrastructures government also needs to make monetary and fiscal policies that would make investing in Nigeria attractive, this would also encourage the private sector especially foreigners to invest thereby creating more employment opportunities.

Human investment is a priority in a populous country like ours,education should be tailored towards the acquisition of skills and technology as relevant and required to meet the needs of modern industries and companies. Skill acquisition, education and training especially technologically is required for human development and provides the gate way for reducing the probability of been or remaining poor. An educational system which is well funded and structured can lead to the removal of beneficiaries from the grip of poverty, ignorance and disease.

If this is to be achieved then there is the need to re-structure the existing too formal and rigid curricular, the introduction of entrepreneurship skills into the curriculum of higher institutions is to be applauded but more still needs to be done especially in terms of acquiring practical skills and hands on training.

The place of the private sector participation should not be ignored in generating employment especially to Nigeria and performing their social responsibilities to their host communities.

In conclusion, the challenge for Nigeria is not one of improving one sector or region at the expense of another or of introducing policy distortions and inefficiencies in resource allocation to benefit one group which in the past has led to increased poverty for others, but to adopt growth and social service oriented policies that will enable all its inhabitants to improve their welfare - A holistic approach. 


\section{References}

[1]. United Nations Organization, United Nations Organization Report, 2001 Edition.

[2]. World Bank, Attacking Poverty, (Oxford : Oxford University Press, World Development Report 2000/2001).

[3]. S Dorothea, Globalisation at work. Finance and Development. 43(1), March, 2006

[4]. International Labour Organisation. Global Employment Trend. ( U.S.A. : ILO Publications, 2004)

[5]. Curtain, generating youth employment through information and telecommunication technologies: best practice examples and strategies. (Melbourne, Australia: Curtain Consulting, 2002)

[6]. Akinfesi, Unemployment in Nigeria .Central Bank Report. (Nigeria: CBN Publication, 1996)

[7]. I Aransi, The impact of corruption on poverty alleviation in Nigeria. Babcock Journal of Economics, Banking and Finance. 1(1), 2009.

[8]. B Aigbokan, Poverty, growth and inequality in Nigeria: a case study. AERC research paper 102. (Nairobi, Kenya: African Economic Research consortium, 2000).

[9]. Idowu, Macroeconomic Theory and Policy. (New York, USA: Harcourt Brace Jovanovich Inc, 1987)

[10]. A Sen, Development: which way now? The Economic Journal 93, December, 1983.

[11]. A Sancho, Policies and programs for social and human development. (A handbook produced for the San Fransisco : United Nations World Summit,1996)

[12]. A Egunjobi, The impact of unemployment and poverty on economic growth in Nigeria. International Journal of Advanced Research in Public Policy, Administration and Development Strategies.Vol.1, No.1, Feb. 2013.

[13]. D Ajakaiye,D and V. Adeyeye, Concepts, measurement and causes of poverty. CBN Economic Review. 39(4), 2003.

[14]. M Jhighan, The economics of development and planning, 37th Edition, (India : Vrinda Publications, 2004).

[15]. P Aku, M. Ibrahim and Y. Bulus, Perspectives on poverty and poverty alleviating strategies for Nigeria. in: Poverty alleviation in Nigeria, selected papers from the 1997 annual conference of Nigerian economic society. 1997.

[16]. E Onwioduokit, Character of unemployment in Nigeria and itslLinks with the macroeconomy. In: Employment generation in Nigeria, Selected Papers for the 2006 Annual Conference of Nigerian Economic Society. 2006

[17]. M Todaro, Economics for A developing World. $2^{\text {nd }}$ edition. (England: Longman UK Limited, 1992).

[18]. J Umo, Economics: An african perspective. (Lagos: Millennium Text Publishers Limited, 2007)

[19]. H Oni, Employment generation: theorectical and empirical issues. (Ibadan: Nigerian Institute of Social and Economic Research, 2006)

[20]. A Iwayemi, Modelling the Nigerian economy for growth and employment. In: Employment generation in Nigeria, Selected Papers for the 2006 Annual Conference of Nigerian Economic Society. 2006

[21]. T Osinubi, Macroeconometric analysis of growth, unemployment and poverty in Nigeria. Pakistan Economic and Social Review.XLIII (2), 2005.

[22]. B Dudley Power and poverty in: Poverty in Nigeria: Proc 1975 Annual Conference of the Nigerian Economic Society. 1975.

[23]. S Fan, L. Zhang and X. Zhang, Growth, inequality and poverty in China: The role of public investments, Research Report 125 , International Food Policy Research Institute, Washington D.C., 2002.

[24]. Steward, Combating poverty: experience and prospect. Finance and Development 27(3) September, 1985.

[25]. M Todaro, Economic development in the Third World. (New York: Longman UK Limited, 1989).

[26]. S Akinyemi et a, 1 Graduate turnout and graduate employment in Nigeria. (Lagos, Nigeria, (n.d))

[27]. A Adebayo, Youth unemployment and national directorate of employment: self employment programmes. Nigerian Journal of Economics and Social Studies.41 (1),1990

[28]. M Obadan, Analytical framework for poverty reduction: issues of economic growth versus other strategies, In: Poverty alleviation in Nigeria, Selected Papers for the 1997 Annual Conference of Nigerian Economic Society. 1997.

[29]. Idowu, Macroeconomic Theory and Policy. (New York, USA: Harcourt Brace Jovanovich Inc, 1987)

[30]. G Mier, Leading issues in economic development. (Oxford: Oxford University Press, 1989)

[31]. M Adebiyi, Debt service- education expenditure nexus: The Nigerian experience. In: Human resource development in West Africa. Selected Papers for the 2002 Annual Conference of Nigerian Economic Society. 2003.

[32]. D Gujarati, Basic econometrics.4th edition. (New Delhi, India : McGraw-Hill Publishing Company, 2003)

[33]. Engle. and C. Granger, (Eds), Long-Run economic relationships: reading in Cointegration. (Oxford: Oxford University Press, 1991). 